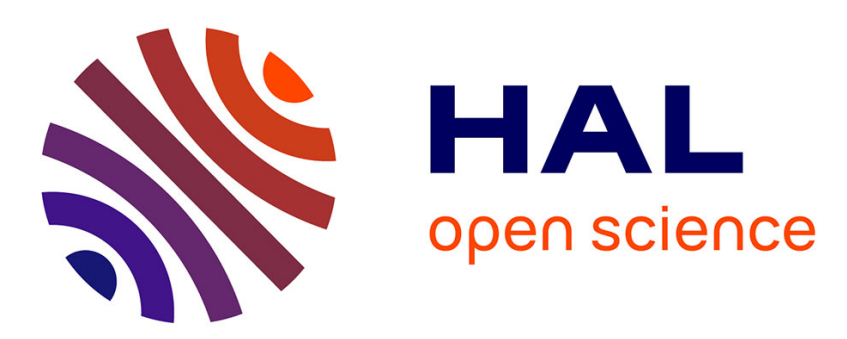

\title{
EFFECT OF SINTERING TEMPERATURE ON HIGH STRAIN RATE PROPERTIES OF IRON POWDER COMPACTS
}

\author{
A. Al-Tounsi, M. Hashmi
}

\section{- To cite this version:}

A. Al-Tounsi, M. Hashmi. EFFECT OF SINTERING TEMPERATURE ON HIGH STRAIN RATE PROPERTIES OF IRON POWDER COMPACTS. Journal de Physique IV Proceedings, 1991, 01 (C3), pp.C3-203-C3-208. 10.1051/jp4:1991327 . jpa-00250469

\section{HAL Id: jpa-00250469 https://hal.science/jpa-00250469}

Submitted on 1 Jan 1991

HAL is a multi-disciplinary open access archive for the deposit and dissemination of scientific research documents, whether they are published or not. The documents may come from teaching and research institutions in France or abroad, or from public or private research centers.
L'archive ouverte pluridisciplinaire HAL, est destinée au dépôt et à la diffusion de documents scientifiques de niveau recherche, publiés ou non, émanant des établissements d'enseignement et de recherche français ou étrangers, des laboratoires publics ou privés. 


\title{
EFFECT OF SINTERING TEMPERATURE ON HIGH STRAIN RATE PROPERTIES OF IROI POWDER COMPACTS
}

\author{
A. AL-TOUNSI and M.S.J. HASHMI \\ School of Mechanical Engineering, Dublin City University, \\ Dublin - 9, Ireland
}

\begin{abstract}
Résumé - On étudie l'effet de la température de frittage sur le comportement mécanique du fer compacté. Les échantillons de fer compacté sont soumis à des vitesses de déformation de $10^{4} \mathrm{~s}^{-1}$. Is sont obtenus par frittage à des températures comprises entre 900 et $1200^{\circ} \mathrm{C}$. Des essais ont également été effectués sur de l'acier doux massif dans la même gamme de vitesses.

ABSTRACT: The effect of sintering temperature on the dynamic behaviour of iron powder compacts is investigated. Iron compacts were subjected to strain rates of upto $10^{+4}$ per second. The compacts were sintered at temperatures ranging from 900 to $1200^{\circ} \mathrm{C}$. Tests were also carried out on solid mild steel specimens at similar range of strain rates.
\end{abstract}

\section{INTRODUCTION}

The subject of powder metallurgy has been given extensive consideration in recent years, and much effort has been directed to the study of producing structural parts from metal powder.

There are many parameters which affect the mechanical properties of sintered parts, such as particle size, green density, sintering time and temperature, alloying elements, sintering atmosphere and so on.

The effect of particle size has been studied by many researchers including those in $\operatorname{Re} F(1,2)$. Viedis(1) investigated the effect of particle size on the ultimate tensile strength for atomized iron powder and found that the ultimate tensile strength for atomized iron powder increases with the decrease in particle size. The effect of sintering time and temperature on the mechanical response has been investigated widely in Refs(3-5). Dunmore(3) studied the effect of varying sintering time and temperature on tensile strength, endurance limit, hardness and elongation for atomized copper powder.

A vast number of research works have appeared in the literature concerning various aspects of powder metallurgy including modified yield criteria ..etc. However it is out of the scope of this work to review them and the reader is directed to seek these elsewhere.

There is a little evidence that the effect of strain rate on the mechanical response of sintered parts has been investigated. Honda(6) carried out tensile test on iron powder compacts at different low strain rates between $10^{-4}$ to $10^{-1}$ per second and reported that tensile strength is almost constant at these rates.

The present work investigates the influence of sintering temperature on the high strain rate, up to $10^{+4}$ per second, behavior of iron powder compacts and a comparison has been made between the behavior of iron compacts and the behavior of solid steel. 


\section{PREPARATION OF TEST PIECES}

Atomized iron powder, $60 \mu$ particle size was mixed with $0.25 \%$ Graphite and $0.75 \%$ Zinc stearate for lubrication purpose in a Y-shaped mixer and compacted by a floating die compaction tool arrangement incorporated in a 50kN INSTRON testing machine. Cylindrical compacts of $10 \mathrm{~mm}$ diameter and $10 \mathrm{~mm}$ height having $85 \%$ relative density were produced.

Sintering was carried out in a tube furnace under controlled atmosphere by a continuous flow of Hydrogen-Argon gas mixture. The compacts were placed inside the furnace which takes about half an hour to heat up from room temperature to the prescribed temperature. The compacts were then left to soak for one hour and subsequently were cooled down inside the furnace. The compacts were sintered at four sintering temperatures 900, 1000,1100 and $1200^{\circ} \mathrm{C}$. For comparison with mild steel, specimens of $5 \mathrm{~mm}$ diameter were machined which were used for the static and dynamic tests.

\section{EXPERIMENTAL PROCEDURE}

The specimens were quasistatically compressed at room temperature using polyethylene sheets as lubricant. The loading was interrupted to introduce a new sheet of polyethylene at intervals of reduction in height. Records of load, current height and diameter were made.

Dynamic tests were carried out using the ballistic testing machine which is capable of producing speeds up to $1000 \mathrm{~m} / \mathrm{sec}$. Specimens were machined from the sintered billets to $5 \mathrm{~mm}$ diameter and $4.5 \mathrm{~mm}$ height. Each test was carried out by placing the specimen on the anvil between two polyethylene sheets to reduce speed was recorded. It should be noted that no barreling occurred and the specimen had a slight mushrooming effect. The test was also done on the mild steel test pieces following the same procedure.

\section{RESULTS}

Fig(1) shows the variation in compression stress with axial strain for the four sintering temperatures. The stress was calculated from the recorded load and the current area which was calculated according to Kuhn (7).

Fig(2) shows the density variation with strain for the four sintering temperatures, where it can be seen that there is not much change in densification with the change in sintering temperature.

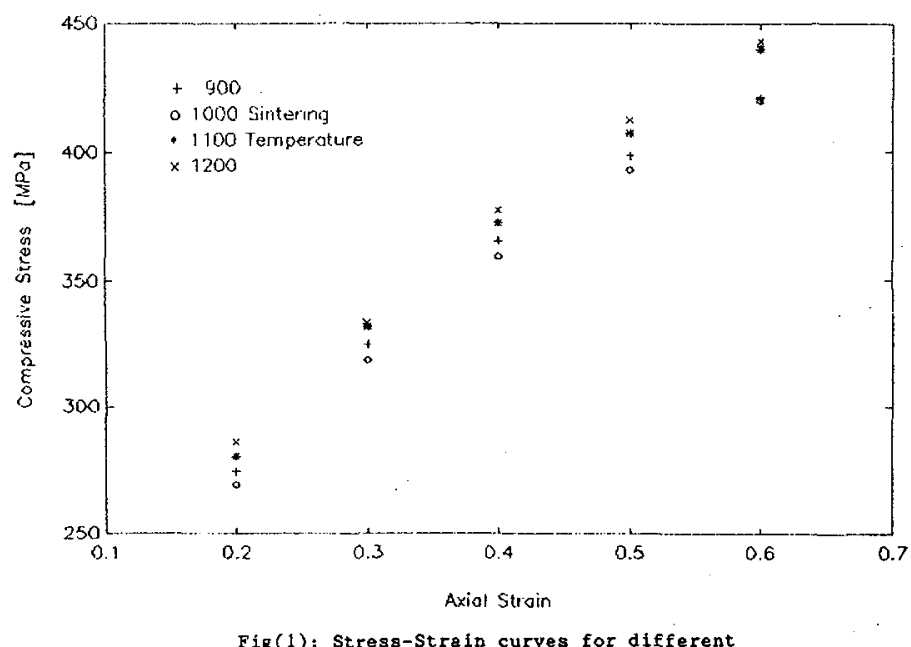

Fig(1): Stress-Strain curves for different sintering temperautres.

The results form the dynamic tests in terms of the final strain were plotted against impact speed for the sintered compacts as shown in Fig(3) along with the mild steel specimens. 
As for mild steel, static tests were carried out at different low strain rates and Fig(4) shows these results.

THE NUMERICAL TECHNIQUE

A finite difference numerical technique was used and modified to analyze theoretically the deformation behaviour of sintered metal compacts during high strain rate upsetting operation. This technique is based on a proposed high strain rate constitutive equation with assumed constants. The technique had previously been reported in $\operatorname{Ref}(8-10)$ in connection with analyzing simple upsetting of cylindrical specimens of elastic strain hardening and strain rate sensitive material.

The stress-strain property of sintered iron compacts is, of course, dependent on the relative density, a parameter which changes during the deformation process. This necessitates a variable relative density dependent material property to be incorporated in any analytical method for predicting deformation characteristics of such material. To this end, the above mentioned numerical technique was modified by incorporating the density changes during deformation and used to predict the simple upsetting of sintered iron compacts based on a proposed high strain rate constitutive equation with assumed values of the constants.

A computer program was developed to simulate the deformation behaviour during impact operation of porous materials. Two equations

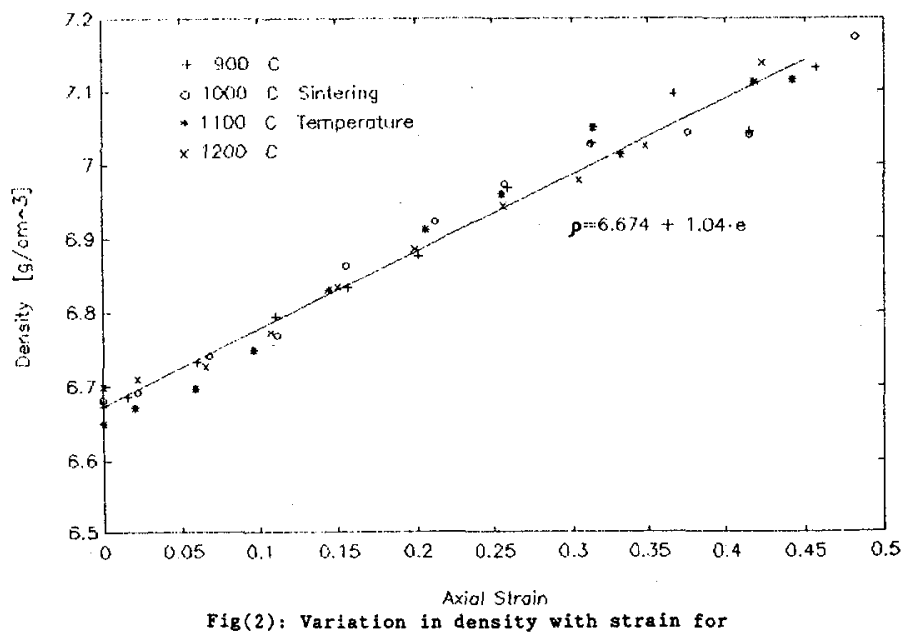
different sintering temperautres.

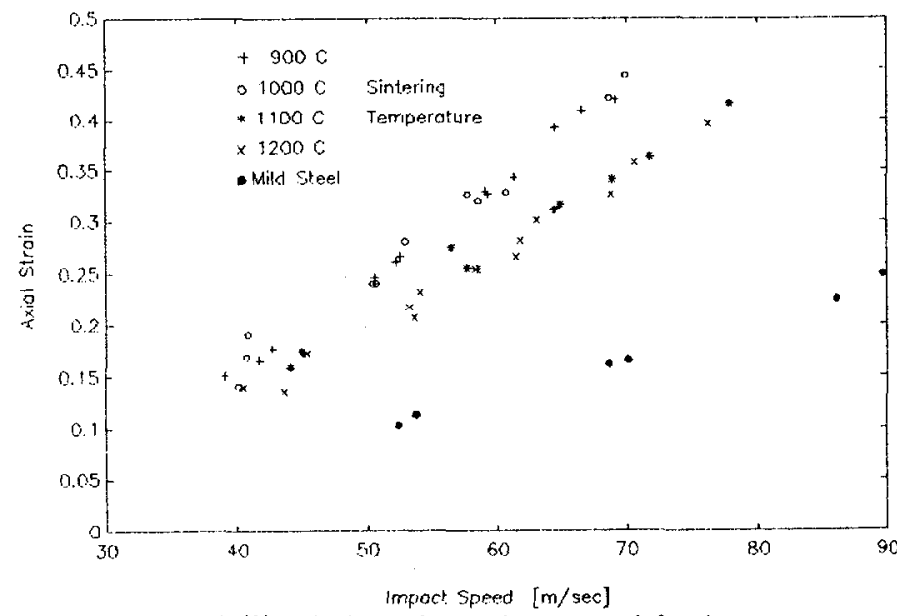

Fig (3): Final strain vs. impact speed for iron compacts and mild steel.

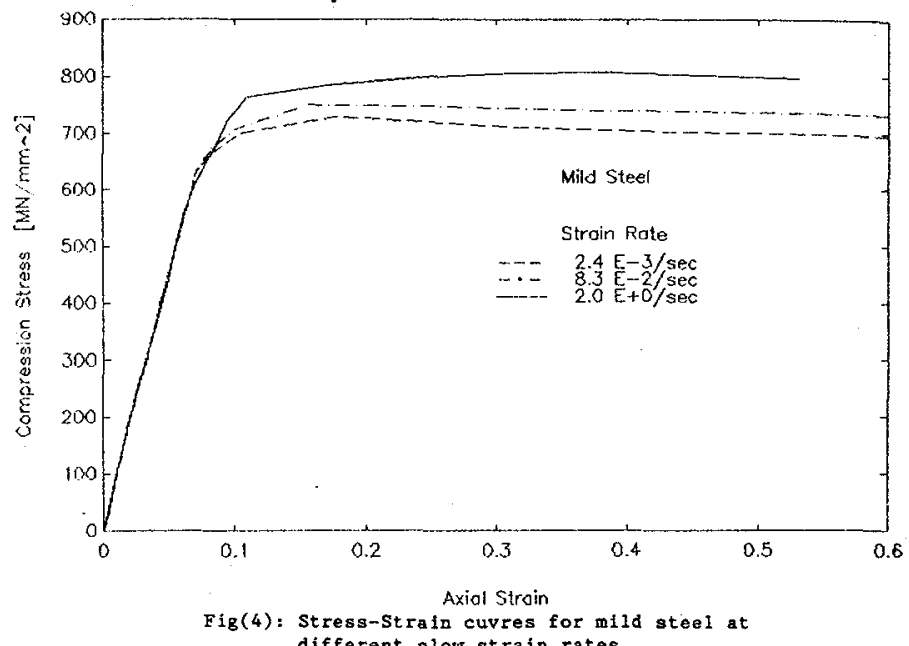
different alow strain rates. 
were introduced in the program, the first takes into account the density changes with strain assuming that the densification behaviour during quasistatic compression is the same as during high strain rate compression. This equation has the form:

$$
R c=R o+a l \cdot E
$$

where $R c$ is the current density, Ro is the initial density, $\epsilon$ is the axial strain and al is a constant which was determined, from the results taken from the static test, using the least square method.

The second is the static constitutive equation for porous materials with a variable relative density dependent material and has the form:

$$
\sigma s=a \cdot e^{b \cdot R_{0}^{c}}
$$

where $\sigma \mathrm{s}$ is the static compression stress and $a, b$ and $c$ are constants which were determined using the results taken from the static test.

The proposed dynamic constitutive equation which is used in the program has the form:

$$
\sigma d=\sigma s \cdot\left[1+(\dot{E} / D)^{\mathrm{P}}\right]
$$

where $\sigma d$ is the dynamic stress, $\dot{\epsilon}$ is the strain rate and $D$ and $P$ are constants. To determine the constants $D$ and $P$, the program was executed with arbitrary initial values for them for each impact speed then the values were changed according to the results from the program

\section{RESULTS AND DISCUSSION}

The values of the strain results from the program were used to fit a curve relating the resultant strain and impact speed which is used in comparing with the experimental curve to see how close the two curves are. Then the procedure was repeated by changing the values of $D$ and $P$ to find the curve which fits very closely with the experimental curve. As for the mild steel specimens the program was executed as explained above taking into account that the density is constant.

Fig (5) shows the resultant curves from the program with the values of $D$ and $P$ for each sintering temperature where it can be seen that there is a good agreement with the experimental results.

Fig(6) shows the variation in the stress ratio between dynamic and static stress with respect to strain rate. This figure also shows the stress ratio with respect to strain rate for solid steel. It can be seen that the results from this investigation show significant difference between the rate sensitivity of mild steel and sintered
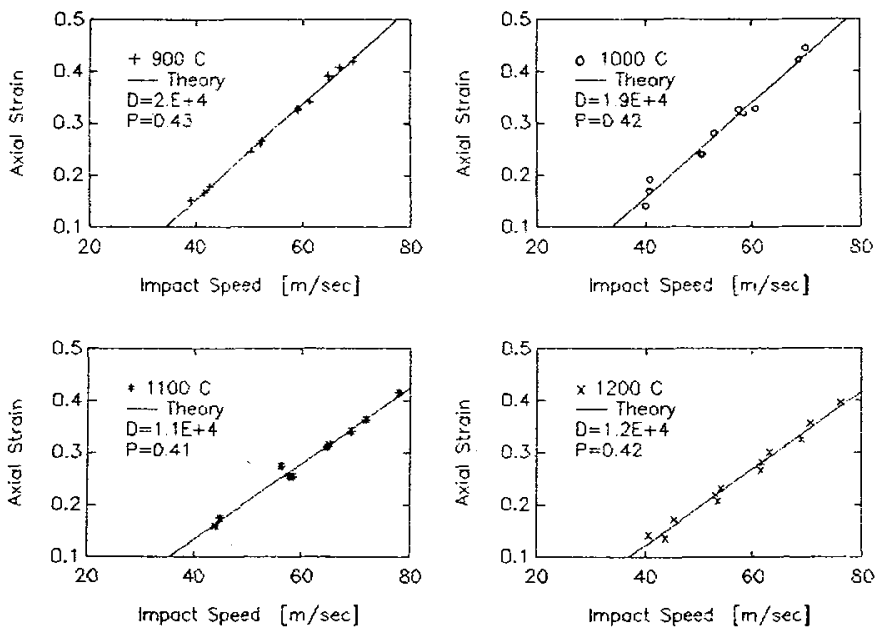

Fig(5): Strain vs. Impact speed for Iron corapacts Theory and experiment. 
Iron compacts and also show some effect of the sintering temperature on the rate sensitivity of sintered compacts.

To verify the theoretical results with the experimental ones, the magnitude of the constants $D$ and $P$ were substituted in equation (3) along with equation (2) to calculate the dynamic stress for different strains. Fig (7) shows the experimental stress-strain curve for Iron compact sintered at $900 . \mathrm{C}$ along with the theoretical curve which was obtained from the analysis where it can be seen that the theoretical analysis gives a slightly higher values for stress than the experimental results and it can also be seen in Fig(8) for mild stee 1 .

\section{CONCLUSIONS}

1- An equation describing the relation between dynamic stress in terms of strain rate was developed by means of a numerical technique in conjunction with the experimental results for strain rates up to $10+4$ per second.

2- The analysis shows that the sintered compacts shows less rate sensitivity than the solid material and there is some effect of sintering temperature on the rate sensitivity of these compacts

\section{ACKNOWLEDGMENT}

The author wishs to thank the Scientific studies and Research Center, Damascus, SYRIA for their moral support in conducting this work.

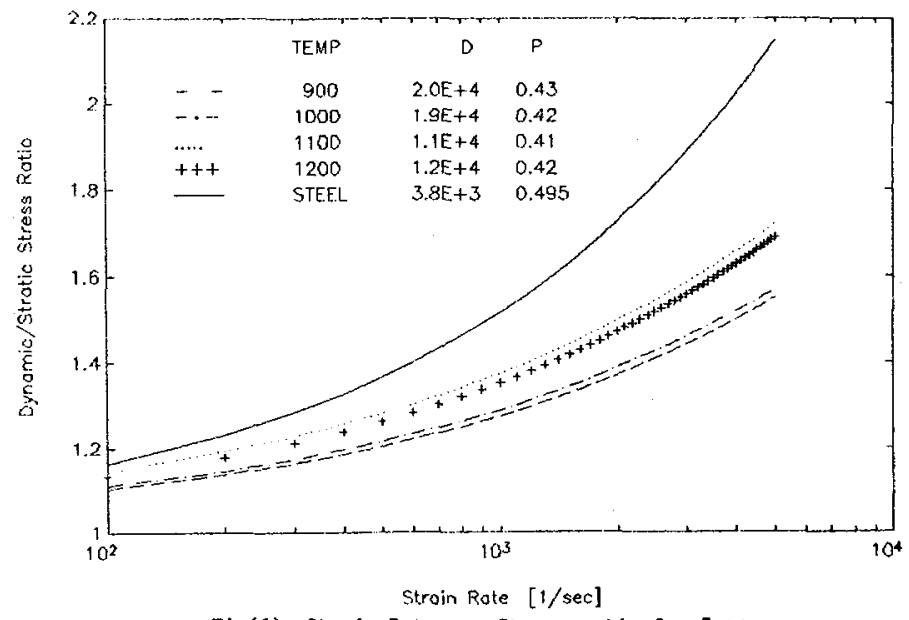

Fig(6): Strain Rate vs. Stress ratio for Iron compacts and mild steel.

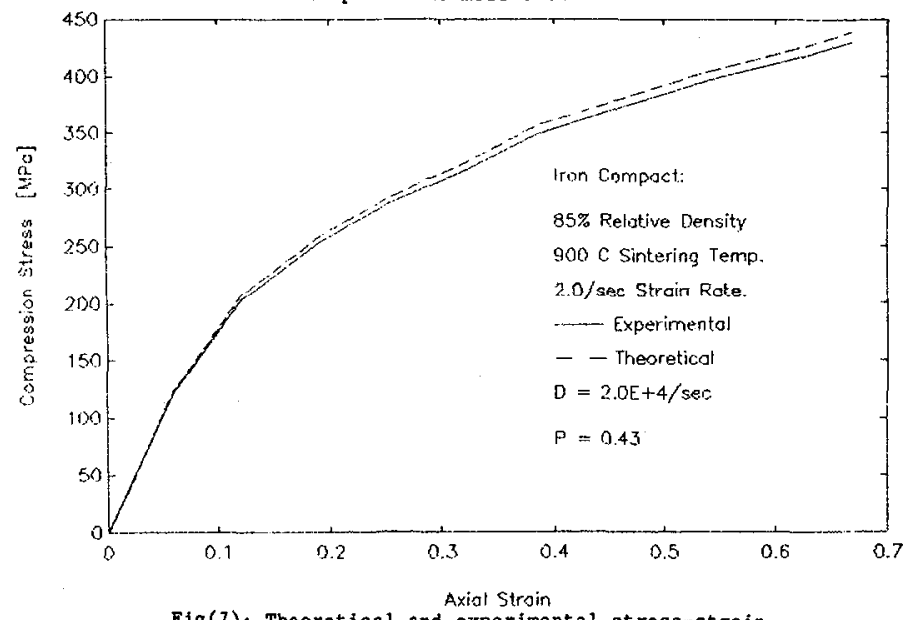

Fig(7): Theoretical and experimental stress-strain curves for Iron compacts.

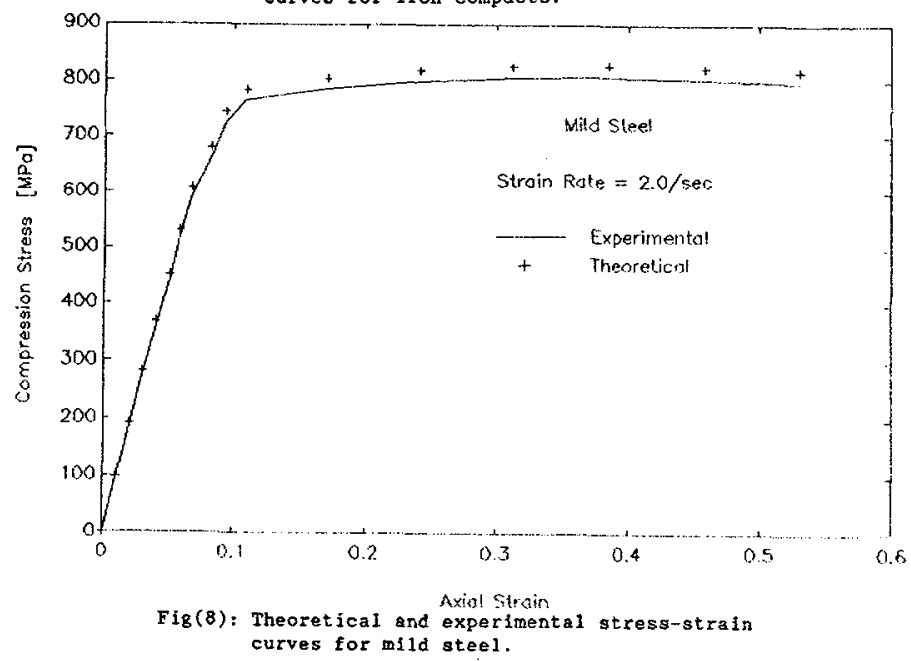




\section{REFERENCES}

1. M.V.VEIDIS \& K.R. GEILING, Int J Powder Metal1. Powder Tech. 17 (2) 1981.

2. TADATOSHI HONDA, J Jpn.Soc. Powder Powder Meta11. 30 (7) 198.

3. O.J.DUNMORE \& G.C. SMITH, The Iron \& Steel Inst. Special Report No.58 1956.

4. A. SQUIRE, Trans. AIME 171,485 (1947).

5. C.G. GOETZEL, J. Inst. Metals 66,319(1940).

6. TADATOSHI HONDA J. Jpn. Soc. Powder Powder Metal1. 23 (2) 1976

7. KUHN, H.A., HAGERTY, M.M., GOIGHER, H.L. \& LAWLEY, A., Int Powder Mera11. Conf, NY., Ju1.1971 vo1 4, Plenum Press 1971.

8. M.S.J. HASHMI \& F.B. KKLEMZ Proc. 17th MTDR Conf. 1976.

9. M.S.J.HASHMI Proc. 18th MTDR Conf. 1977.

10.F.B. KLEMZ CNAA Ph.D Thesis, Shefield City Polytechnic 1985. 